\title{
Effect of dual $B t$-expression transformation vectors on transgene expression in tobacco
}

\author{
L.N. Xu ${ }^{1,2 *}$, Y. Dong ${ }^{1,2 *}$, J. Zhang ${ }^{1,2}$, R.X. Wang ${ }^{1}$, H.M. Liu ${ }^{1}$, Q. Yang ${ }^{1}$ and \\ M.S. Yang ${ }^{1,2}$ \\ ${ }^{1}$ Institute of Forest Biotechnology, Forestry College, \\ Agricultural University of Hebei, Baoding, China \\ ${ }^{2}$ Hebei Key Laboratory for Tree Genetic Resources and Forest Protection, \\ Baoding, China \\ *These authors contributed equally to this study. \\ Corresponding author: M.S. Yang \\ E-mail: yangms100@126.com
}

Genet. Mol. Res. 15 (3): gmr.15038293

Received December 16, 2015

Accepted February 26, 2016

Published July 29, 2016

DOI http://dx.doi.org/10.4238/gmr.15038293

Copyright (C) 2016 The Authors. This is an open-access article distributed under the terms of the Creative Commons Attribution ShareAlike (CC BY-SA) 4.0 License.

ABSTRACT. This study aimed to determine the influence of vector
structure on dual $B t$ gene expression and establish an efficient
expression vector using Cry $1 A c$ and $C r y 3 A$ genes. Four vectors (N4,
$\mathrm{N} 5, \mathrm{~N} 10$, and S23) were developed and used for genetic transformation
of tobacco to obtain insect-resistant transgenic lines. The vectors were
constructed using the MAR structure, applying different promoter and
enhancer sequences, and changing the transgene open-reading frame
sequence. The average Cry1Ac toxalbumin expression quantity was
67 times higher in N5 than in N4 transgenic lines ( 8.77 and $0.13 \mu \mathrm{g} / \mathrm{g}$,
respectively). In contrast, the average Cry $3 \mathrm{~A}$ toxalbumin expression
quantity was 1.5 times higher in N4 than in N5 lines (12.70 and 8.21
$\mu \mathrm{g} / \mathrm{g}$, respectively). The sequences of both $B t$ genes significantly
influenced toxalbumin expression, although upstream Bt genes

Genetics and Molecular Research 15 (3): gmr.15038293 
presented lower expression levels. The average Cry1Ac toxalbumin content was 13 times higher in the transgenic lines of AtADH 5'-nontranslated sequence N5 $(8.77 \mu \mathrm{g} / \mathrm{g})$ than in the omega N10 lines $(0.67$ $\mu \mathrm{g} / \mathrm{g})$. Furthermore, the average Cry1 Ac toxalbumin content was 5 times higher in MAR N5 than in non-MAR S23 lines (8.77 and 1.63 $\mu \mathrm{g} / \mathrm{g}$, respectively). The average Cry3A toxalbumin content was 1.3 times higher in N5 than in S23 lines (8.21 and $6.48 \mu \mathrm{g} / \mathrm{g}$, respectively). Moreover, toxalbumin expression levels differed significantly among the S23-transformed lines. The MAR structure applied on both ends of the genes increased both the level and stability of exogenous gene expression. In conclusion, N5 was the most optimal of the four tested vectors.

Key words: Tobacco; Plant expression vector; Dual Bt gene; Genetic transformation; Differential expression; Insect-resistance

\section{INTRODUCTION}

With the rapid development of molecular biology techniques, scholars have considerably progressed in transgenic plant analysis. Currently, Bacillus thuringiensis $(B t)$ is one of the most extensively used and promising insecticidal genes. Many types of $B t$ genes have been successfully transferred to tobacco, corn, cotton, poplar, and other plants. Thus, a large number of plants with high insect resistance have been produced for commercial production. By using transgenic plants, less pesticide is required resulting in great economic benefits (Fromm et al., 1990; Koziel et al., 1993; Stewart et al., 2001; Wang et al., 2008a; Zhang et al., 2012; Liao et al., 2015). Depending on which Bt gene is transferred to the plant, a certain degree of resistance to a certain kind of insect is conferred. For example, plants transformed with CrylAc can only resist Lepidoptera (Whiteley and Schnepf, 1986; Wang et al., 2008b; Zhang et al., 2015), whereas those transformed with Cry3A can only resist Coleoptera (Sekar et al., 1987; Yang et al., 2003; Zhang et al., 2006). As such, many researchers have aimed to transfer multiple $B t$ genes into plants, both to improve insect resistance and to expand the insect-resistance spectrum (Fan et al., 1999; Su et al., 2002; Tabashnik et al., 2009; Addison and Rogers, 2010; Zhang et al., 2012; Wang et al., 2012).

High sequence similarity or identity among different $B t$ genes may affect their expression. Furthermore, if $B t$ genes resisting different kinds of pests are constructed on a vector and transferred to a plant, little or no expression may occur (Wang et al., 2012). It is therefore necessary to develop transgenic plants with efficient and simultaneous expression of multiple $B t$ genes.

In this experiment, two $B t$ genes were constructed on a vector by utilizing the matrix attachment region (MAR) structure, applying different promoters (Cui et al., 2015) and enhancer sequences, and changing the open reading frame (ORF) sequence of exogenous genes. Four different types of vectors were constructed and transferred to tobacco, to obtain transgenic plants. The optimal combination of $B t$ genes was determined, and transgenic plants with high expression and a broad spectrum of insect resistance were identified. This study constitutes a basis for breeding insect-resistant transgenic plants.

Genetics and Molecular Research 15 (3): gmr.15038293 


\section{MATERIAL AND METHODS}

\section{Strains and vectors}

The existing plasmid and two isocaudamer systems (NotI/Bsp120I and SpeI/XbaI/ NheI) were used to construct a multi-gene plant transformation vector system. The vector system included a transformation vector containing the restriction enzyme cutting sites Bsp120I and $X b a \mathrm{I}$, as well as a cloning vector that contained the restriction enzyme cutting sites NotI, Bsp120I, SpeI, and NheI. The ORF of the new target genes was connected to the transformation vector. The original restriction enzyme cutting site was removed after connection to the isocaudamer. The features and structures of the four transformation vectors constructed are shown in Table 1 and Figure 1, respectively. Plasmid vectors were constructed and introduced into Agrobacterium GV3101 at the Forest Tree Genetic Breeding Laboratory of Hebei Agricultural University.

Table 1. Features of the four plant transformation vectors (selectable marker gene is $n p t I I$ ).

\begin{tabular}{l|l|l|l|l}
\hline Vector No. & Vector name & Gene sequence & MAR structure & Enhancer \\
\hline N4 & p71A68Y71 & CrylAc before $C r y 3 A$ & Yes & AtADH 5'-UTR \\
\hline N5 & p71Y71A68 & Cry3A before $C r y 1 A c$ & Yes & AtADH 5'-UTR \\
\hline N10 & p71Y71C68 & Cry3A before CrylAc & Yes & Omega sequence \\
\hline S23 & p09Y71A68 & Cry3A before CrylAc & No & AtADH 5'-UTR \\
\hline
\end{tabular}
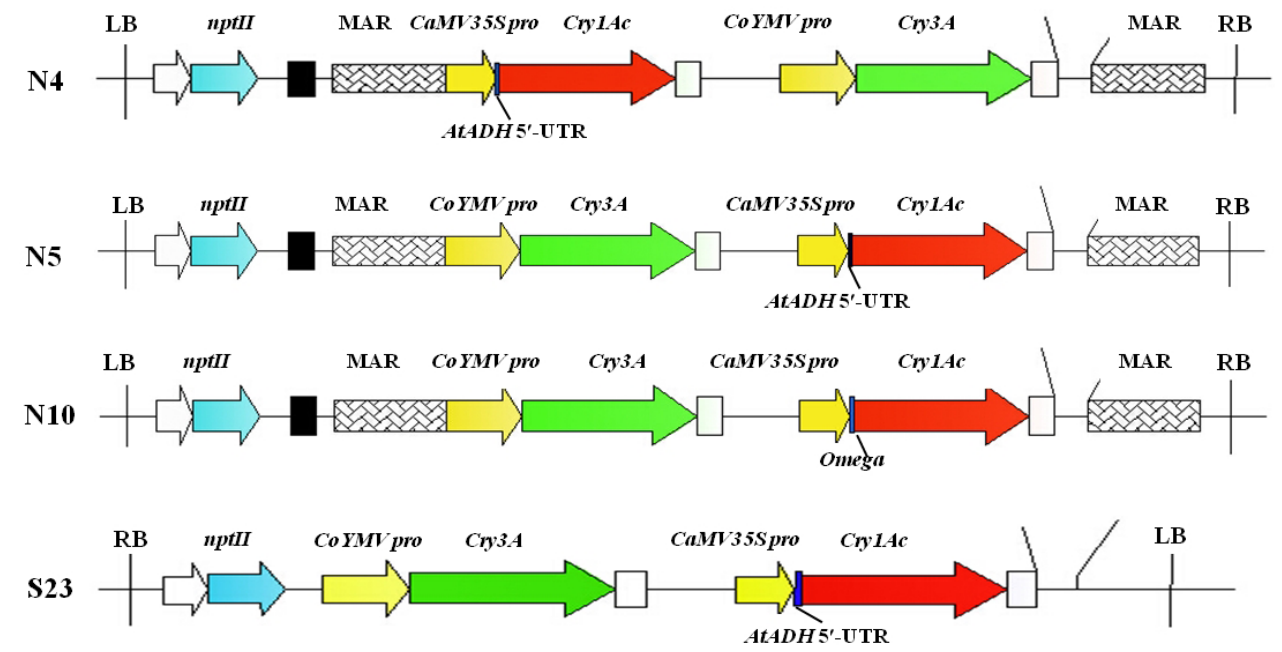

Figure 1. Flow chart of the structure of the four plant transformation vectors.

\section{Plants and insects}

Samples from 'winsconsin35' tobacco plants were obtained from the Academy of Forestry of Hebei Agricultural University. The plantlets were placed in a culture room at $25^{\circ}$ $\pm 2{ }^{\circ} \mathrm{C}$ at a light intensity of $2000 \mathrm{Lx}$ and a light/dark cycle of $14 / 10 \mathrm{~h}$. Helicoverpa armigera 
(Hubner) (Lepidoptera, Noctuidae) were purchased from Henan Jiyuan Baiyun Industrial Co., Ltd. Apriona germari (Hope) (Coleoptera, Cerambycidae) were obtained from the Academy of Forestry of Hebei Agricultural University. Both H. armigera and A. germari were cultured at room temperature.

\section{Agrobacterium-mediated transformation of tobacco through leaf disc method}

Streak cultivation was conducted against Agrobacterium GV3101 on $25 \mathrm{~mL}$ yeast extract broth (YEB) solid medium containing $25 \mathrm{mg} / \mathrm{L}$ rifampicin (Rif) and $50 \mathrm{mg} / \mathrm{L}$ kanamycin (Kan) (Sangon Biotech, Shanghai, China) with small amounts of the transformation vectors. A single colony was selected and planted in $40 \mathrm{~mL}$ YEB liquid medium containing the same concentrations of Kan and Rif at $28^{\circ} \mathrm{C}$. The medium was shaken at $150 \mathrm{rpm}$ until the liquid became turbid. We collected $10 \%$ of the bacterial liquid solution and poured it in $40 \mathrm{~mL}$ YEB liquid medium containing Rif and Kan. The medium was shaken until $\mathrm{OD}_{600}=0.4-0.6$, and infection fluid was obtained.

Sterile, robust, and bright green tobacco plantlets were selected and cut along the veins into $0.5-1-\mathrm{cm}^{2}$ small pieces. The plantlets were infected for $8 \mathrm{~min}$ with infection fluid diluted in 5\% sucrose solution (1:1). The samples were then collected and dried with sterile absorbent paper. The samples were placed into co-culture medium [MS $+2.0 \mathrm{mg} / \mathrm{L}$ 6-benzylaminopurine $(6-\mathrm{BA})+0.1 \mathrm{mg} / \mathrm{L}$ indole-3-butyric acid (IBA) $]$ in the dark for 2 days and then transferred to filtering medium [MS $+2.0 \mathrm{mg} / \mathrm{L} 6-\mathrm{BA}+0.1 \mathrm{mg} / \mathrm{L} \mathrm{IBA}+100 \mathrm{mg} / \mathrm{L} \mathrm{Kan}+300 \mathrm{mg} / \mathrm{L}$ cefotaxime (Cef)]. The filtering medium was replaced every 2 weeks. Resistant shoots $(2 \mathrm{~cm}$ in length) were transplanted into root medium $(1 / 2 \mathrm{MS}+100 \mathrm{mg} / \mathrm{L} \mathrm{Kan}+300 \mathrm{mg} / \mathrm{L} \mathrm{Cef})$ for screening. The medium was placed in a culture room at $25^{\circ} \pm 2^{\circ} \mathrm{C}$ at a light intensity of $2000 \mathrm{Lx}$ and a light/dark cycle of $14 / 10 \mathrm{~h}$. Plants in the rooting medium were propagated and transplanted to the nursery after acclimatization. To avoid the effect of random transgene insertion on gene expression, 8-10 lines were transformed with each vector, each line consisted of 10 samples.

\section{Polymerase chain reaction (PCR) detection of transgenic lines}

Leaves collected from the different lines and non-GM tobacco seedlings were transplanted to the field after 2-3 weeks. DNA was extracted from lines transformed with the four kinds of vectors (N4, N5, N10, and S23; Table 1) and control tobacco using the modified CTAB method (He et al., 2011). Primers were designed according to the full-sequence information of the target genes found in the NCBI database. A PCR was conducted to determine whether the target genes had been integrated into the tobacco genome. The CrylAc (546 bp) and Cry $3 \mathrm{~A}$ (667 bp) fragments were amplified. Primer $C r y l A c$; forward: 5'-ATGGATAACAATCCGAA CATCA-3' and reverse: 5'-CCACCTTTGTCCAAACACTGAA-3' and primer Cry3A; forward: 5'-CACTGTTCCCACTGTACGATGT-3' and reverse: 5'-ATGTTGAAGAAGTCCACG CTCT-3'. The PCR kit was purchased from Bio-Rad Chromo4 Company in USA.

Each target gene was detected through a PCR using a $20-\mu \mathrm{L}$ reaction volume containing $8 \mu \mathrm{L} \mathrm{ddH_{2 }} \mathrm{O}, 10 \mu \mathrm{L}$ MIX, $0.5 \mu \mathrm{L}$ forward primer $(20 \mu \mathrm{M}), 0.5 \mu \mathrm{L}$ reverse primer $\mathrm{R}$ $(20 \mu \mathrm{M})$, and $1 \mu \mathrm{L}$ DNA. The PCR program for the detection of CrylAc and Cry $3 A$ included the following: initial denaturation at $95^{\circ} \mathrm{C}$ for $5 \mathrm{~min} ; 25$ denaturation cycles at $94^{\circ} \mathrm{C}$ for $50 \mathrm{~s}$, renaturation at $50^{\circ} \mathrm{C}$ for $55 \mathrm{~s}$, and extension at $72^{\circ} \mathrm{C}$ for $1 \mathrm{~min}$; followed by a final extension

Genetics and Molecular Research 15 (3): gmr.15038293 
at $72^{\circ} \mathrm{C}$ for 2 min. The model of the PCR equipment was T3 Biometra Company in Germany and the PCR reagents were purchased from Sangon Biotech.

\section{Enzyme-linked immunosorbent assay (ELISA) of Bt toxalbumin}

Three randomly selected lines from transgenic and control lines were planted in the nursery garden in July 2014. Third leaves were selected in a top-down manner and collected for Bt protein detection. Bt-Cry1Ab/1Ac ELISA and Bt-Cry3A ELISA protein detection kits (Agdia) were used for Cry1Ac and Cry3A detection, respectively. A positive control was provided in the kit and the non-transgenic tobacco was used as negative control. Detection was performed following the manufacturer instructions and a Bio-Rad 550 microplate reader (Bio-Rad Laboratories, USA) was used for determination. The protein concentrations were calculated as toxalbumin $(\mu \mathrm{g})$ per gram of fresh leaves.

\section{Fluorescence quantitative (FQ) PCR detection}

Leaves were collected from control tobacco seedlings and from three samples of each transgenic line transformed with each vector with the highest expression of Cry1Ac and Cry3A toxalbumin. The leaves were transplanted to the field in July 2014 for 3 months. The leaves were then placed in liquid nitrogen and transported back to the laboratory. Leaves weighing $100 \mathrm{mg}$ were placed in a mortar together with liquid nitrogen and quickly ground into powder. Total RNA was extracted using Ultrapure RNA extraction kit (Kangwei Century) following the manufacturer instructions. Inverse transcription was conducted against the first cDNA chain by using TUREscript First-Strand cDNA synthesis kit (reversetranscription kit; Beijing AidLab Company). FQ-PCR primers were designed according to the full-sequence information of target genes found in the NCBI database. cDNA compounded through reverse transcription was used as the template, and 2X Sybr Green qPCR Mix was used for FQ-PCR detection. The primers used for the FQ-PCR detection were forward: 5'-GAATTTTTGGTCCCTCTCAAT-3' and reverse: 5'-AGGATCTGCTTCCCACTCTCT-3' for CrylAc; and forward: 5'-TGGGGATACGAGAAGGAGGAT-3' and reverse: 5'-AGTGGGAACAGTGCGATGAGA-3' for Cry $3 A$.

The $20-\mu \mathrm{L}$ reaction solution contained $10 \mu \mathrm{L} 2 \mathrm{X}$ SYBR qPCR Mix, $0.5 \mu \mathrm{L}$ forward primer $(10 \mu \mathrm{M}), 0.5 \mu \mathrm{L}$ reverse primer $(10 \mu \mathrm{M}), 1 \mu \mathrm{L}$ template, and $8 \mu \mathrm{LddH}_{2} \mathrm{O}$. The reaction procedure was as follows: initial denaturation at $95^{\circ} \mathrm{C}$ for $5 \mathrm{~min}$, denaturation at $95^{\circ} \mathrm{C}$ for $10 \mathrm{~s}$, and renaturation at $55^{\circ} \mathrm{C}$ for $30 \mathrm{~s}$. The standard used consisted of plasmid DNA of known fragment size and contained both $C r y l A c$ and $C r y 3 A$. The standard was diluted 10 times and applied to form a standard curve in a real-time FQ-PCR. The recurring number at which the fluorescent signal reached the pre-set threshold and the standard curve were used to calculate the transcription abundance of $B t$ in cDNA compounded with pri-miRNA. We used

Bio-Rad Chromo4 FQ-PCR equipment and all FQ-PCR detection reagents were purchased from Shanghai Sangon Company.

\section{Insect-resistance test}

H. armigera larvae were used to determine the insect-resistance of Cry1 Ac toxalbumin. The larvae were cultured from purchased egg clusters, and the hatched first instar larvae were

Genetics and Molecular Research 15 (3): gmr.15038293 
directly used in the feeding experiment. In July 2014, leaves of the three vector transformed lines with the highest level of Cry1Ac toxalbumin expression were fed to the $H$. armigera larvae. The petiole was inserted into moist soil to maintain leaf freshness. Thirty larvae were carefully and evenly placed on each leaf, which was placed in a $6.5-\mathrm{cm}$ wide and $8-\mathrm{cm}$ high beaker. The beaker rims were covered and tied with double-layer moist gauze, and were placed in gently sealed plastic bags to maintain moisture and air permeability. Five replicates were performed, and each strain was placed in a beaker. The tobacco leaves were replaced daily. The number of instars and deaths were recorded, and the feeding experiment was terminated when the number of larvae reached a stable level. Data were summarized and used to calculate average cumulative mortality rate.

A. germari were used to determine the insect resistance of Cry3A toxalbumin. Adult $A$. germari were bred indoors and newly hatched larvae were used in the feeding experiment. In July 2014, leaves of the vector-transformed lines with the highest level of Cry3A toxalbumin expression were fed to A. germari. Leaves collected from each strain and the current-year branches of the non-transgenic Populus tomentosa (P. tomentosa, a tree suffering greatly from A. germari), were mixed at a 1:1 ratio and ground with a pulverizer. The powdered feed and newly hatched larvae were placed in thimble tubes, with one tube provided per larva. Five replicates were set for each strain. The larval weight on the first day of incubation was set as the basal weight. The powdered feed was replaced every 2 days, and the larvae were weighed and fed continuously for 12 days. Insect growth rate was calculated as the weight obtained at a designated time - the basal weight divided by the basal weight $\mathrm{x} 100$.

\section{Data analysis}

Microsoft Excel 2007 and DPS v. 7.05 statistical analysis softwares were used for data processing. Duncan's new multiple range method was used for multiple comparison of significant index differences.

\section{RESULTS}

\section{Acquisition of transgenic lines}

In the screening of the different media, the transgenic tobacco yielded differentiated resistant buds whereas non-transgenic tobacco failed to differentiate. The resistant buds were transplanted to the rooting medium. The four transformation vectors $(\mathrm{N} 4, \mathrm{~N} 5, \mathrm{~N} 10$, and S23) each resulted in 8, 10, 10, and 10 rooting lines, whereas the control group failed to

root altogether. The lines were transplanted to flower pots and, following domestication, to the field. Thirty-eight transgenic lines transformed with the four vectors were preliminarily selected using Kan (Figure 2).

\section{PCR detection of transgenic lines}

The results of the PCR amplification of $C r y 1 A c$ and $C r y 3 A$ showed amplification of target stripes of 546 and $667 \mathrm{bp}$, respectively, from all 38 lines and the positive control. The PCR detection results in which the target genes had been integrated into the tobacco genome are presented in Table 2 and Figure 3.

Genetics and Molecular Research 15 (3): gmr.15038293 


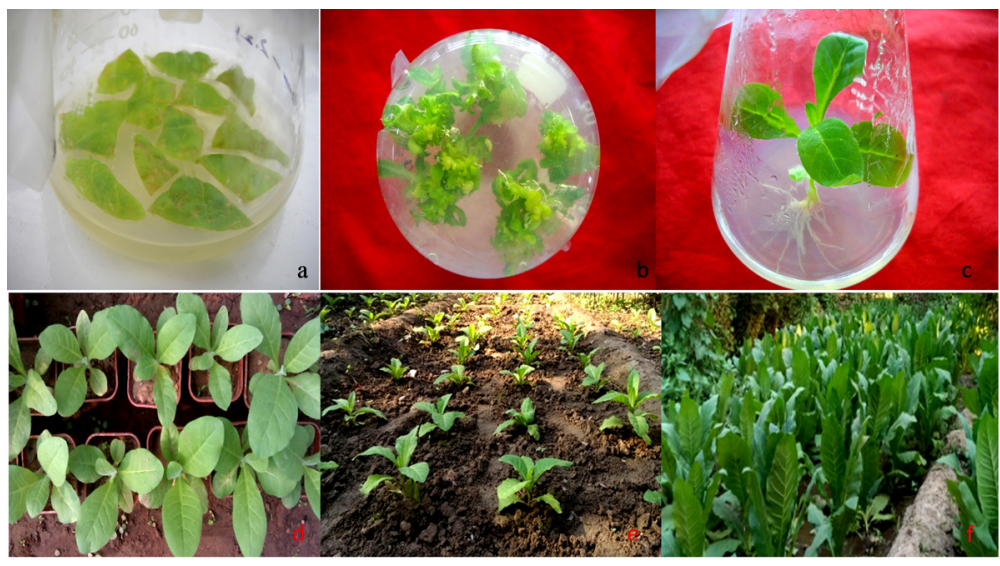

Figure 2. Acquisition of transgenic plants. a. Leaves after Agrobacterium infection. b. Leaves growing shoots and the proliferation of resistant shoots. c. Rooting of resistant shoots. d. Rooting plants transplanted to small pots. e. Rooting plants transplanted to soil. f. Thriving field plants.

Table 2. Results of PCR detection for lines of the four vectors and the control dual Bt genes.

\begin{tabular}{|c|c|c|c|c|c|c|c|c|c|c|c|}
\hline \multirow[t]{2}{*}{ Gene type } & \multirow[t]{2}{*}{ Vectors } & \multicolumn{10}{|c|}{ No. of lines } \\
\hline & & 1 & 2 & 3 & 4 & 5 & 6 & 7 & 8 & 9 & 10 \\
\hline \multirow[t]{6}{*}{ Amplified result of $C r y l A c$} & $\mathrm{~N} 4$ & + & + & + & + & + & + & + & + & & \\
\hline & N5 & + & + & + & + & + & + & + & + & + & + \\
\hline & N10 & + & + & + & + & + & + & + & + & + & + \\
\hline & S23 & + & + & + & + & + & + & + & + & + & + \\
\hline & $\mathrm{CK}+$ & + & & & & & & & & & \\
\hline & CK- & - & & & & & & & & & \\
\hline \multirow[t]{6}{*}{ Amplified result of $\mathrm{Cry} 3 \mathrm{~A}$} & $\mathrm{~N} 4$ & + & + & + & + & + & + & + & + & & \\
\hline & N5 & + & $\begin{array}{lll}+ & \\
\end{array}$ & + & + & $\begin{array}{lll}+ & & \end{array}$ & + & + & + & + & + \\
\hline & N10 & + & + & + & + & + & + & + & + & + & + \\
\hline & S23 & + & + & + & + & + & + & + & + & + & + \\
\hline & CK+ & + & & & & & & & & & \\
\hline & CK- & - & & & & & & & & & \\
\hline
\end{tabular}

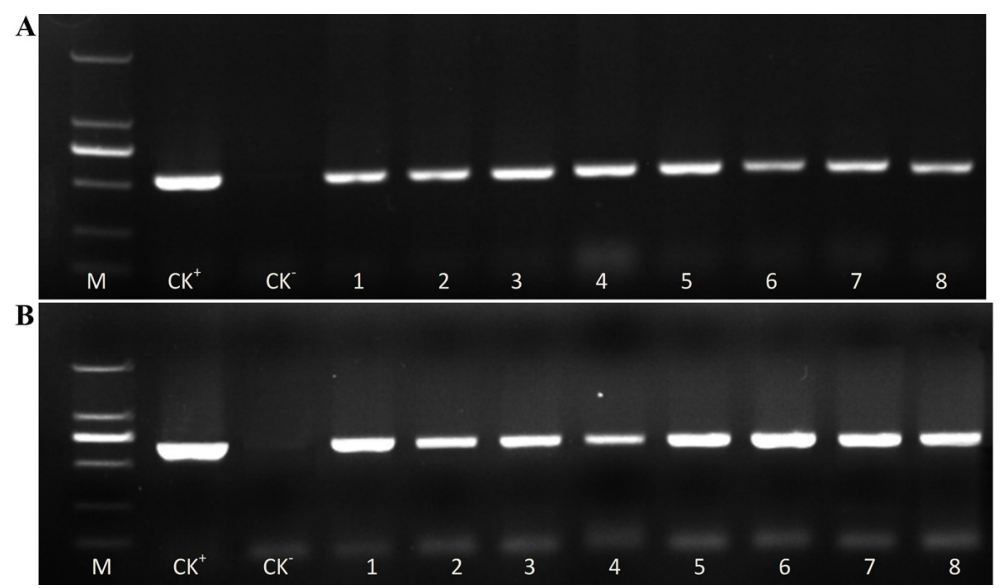

Figure 3. PCR detection of the $\operatorname{Cry} 1 A c(\mathbf{A})$ and $\operatorname{Cry} 3 A(\mathbf{B})$ genes of eight transgenic tobacco N4 lines. Lane M: DL2000 DNA marker indicating (from top to bottom) 2000, 1000, 750, 500, 250, and $100 \mathrm{bp}$; CK+: plasmid; CK-: control (untransformed line).

Genetics and Molecular Research 15 (3): gmr.15038293 


\section{ELISA detection of toxalbumin}

As shown in the Cry1 Ac toxalbumin detection results (Table 3), toxalbumin expression was detected in all lines and differed significantly both among the different lines and vectors $(\mathrm{P} \leq 0.05)$. The lowest average toxalbumin expression level was observed in N4-transformed lines $(0.13 \mu \mathrm{g} / \mathrm{g})$, whereas the highest expression was detected in N5-transformed lines $(8.77$ $\mu \mathrm{g} / \mathrm{g}$ ). The expression levels in the N10- and S23-transformed lines were 0.67 and $1.63 \mu \mathrm{g} / \mathrm{g}$, respectively.

Table 3. Toxalbumin content of Cry1Ac and Cry3A in lines transformed from the four vectors.

\begin{tabular}{|c|c|c|c|c|c|}
\hline \multirow[t]{2}{*}{ Vectors } & \multirow[t]{2}{*}{ Line No. } & \multicolumn{2}{|c|}{ CrylAc toxic protein content $(\mu \mathrm{g} / \mathrm{g})$} & \multicolumn{2}{|c|}{ Cry3A toxic protein content $(\mu \mathrm{g} / \mathrm{g})$} \\
\hline & & Line average & Vector average & Line average & Vector average \\
\hline \multirow[t]{8}{*}{$\mathrm{N} 4$} & N4-1 & $0.10 \pm 0.01^{\mathrm{c}}$ & \multirow[t]{8}{*}{$0.13 \pm 0.04^{\mathrm{c}}$} & $8.39 \pm 0.53^{\mathrm{e}}$ & \multirow[t]{8}{*}{$12.70 \pm 3.90^{\mathrm{a}}$} \\
\hline & $\mathrm{N} 4-2$ & $0.17 \pm 0.01^{\mathrm{a}}$ & & $9.84 \pm 1.45^{\mathrm{de}}$ & \\
\hline & N4-3 & $0.13 \pm 0.01^{\mathrm{b}}$ & & $20.34 \pm 0.78^{\mathrm{a}}$ & \\
\hline & $\mathrm{N} 4-4$ & $0.09 \pm 0.01^{\mathrm{c}}$ & & $11.61 \pm 1.48^{\text {cd }}$ & \\
\hline & $\mathrm{N} 4-5$ & $0.13 \pm 0.01^{\mathrm{b}}$ & & $15.86 \pm 2.17^{\mathrm{b}}$ & \\
\hline & N4-6 & $0.15 \pm 0.04^{\mathrm{b}}$ & & $11.19 \pm 1.65^{\mathrm{d}}$ & \\
\hline & N4-7 & $0.18 \pm 0.01^{\mathrm{a}}$ & & $14.08 \pm 0.92^{\mathrm{bc}}$ & \\
\hline & $\mathrm{N} 4-8$ & $0.06 \pm 0.03^{\mathrm{d}}$ & & $10.29 \pm 1.34^{\mathrm{de}}$ & \\
\hline \multirow[t]{10}{*}{ N5 } & N5-1 & $9.89 \pm 1.00^{\mathrm{a}}$ & \multirow[t]{10}{*}{$8.77 \pm 1.44^{\mathrm{a}}$} & $9.43 \pm 0.69^{\mathrm{abc}}$ & \multirow[t]{10}{*}{$8.21 \pm 2.63^{\mathrm{b}}$} \\
\hline & N5-2 & $9.16 \pm 1.07^{\mathrm{a}}$ & & $12.43 \pm 2.33^{\mathrm{a}}$ & \\
\hline & N5-3 & $7.12 \pm 1.42^{\mathrm{a}}$ & & $5.81 \pm 0.73^{\mathrm{cd}}$ & \\
\hline & N5-4 & $6.85 \pm 2.70^{\mathrm{a}}$ & & $7.45 \pm 1.93^{\mathrm{bc}}$ & \\
\hline & N5-5 & $9.60 \pm 0.18^{\mathrm{a}}$ & & $6.56 \pm 0.77^{\mathrm{dd}}$ & \\
\hline & N5-6 & $9.75 \pm 0.21^{\mathrm{a}}$ & & $8.03 \pm 2.81^{\mathrm{bc}}$ & \\
\hline & N5-7 & $9.74 \pm 0.73^{\mathrm{a}}$ & & $9.23 \pm 2.21^{\mathrm{abc}}$ & \\
\hline & N5-8 & $6.22 \pm 5.17^{\mathrm{a}}$ & & $11.00 \pm 2.68^{\mathrm{ab}}$ & \\
\hline & N5-9 & $9.95 \pm 0.40^{\mathrm{a}}$ & & $8.87 \pm 1.04^{\mathrm{abc}}$ & \\
\hline & N5-10 & $9.42 \pm 0.81^{\mathrm{a}}$ & & $3.25 \pm 1.02^{\mathrm{de}}$ & \\
\hline \multirow[t]{10}{*}{ N10 } & N10-1 & $0.94 \pm 0.04^{\mathrm{a}}$ & \multirow[t]{10}{*}{$0.67 \pm 0.40^{\mathrm{c}}$} & $7.53 \pm 0.73^{\mathrm{a}}$ & \multirow[t]{10}{*}{$3.46 \pm 3.41^{\mathrm{c}}$} \\
\hline & $\mathrm{N} 10-2$ & $0.87 \pm 0.01^{\mathrm{a}}$ & & $0.42 \pm 0.09^{\mathrm{de}}$ & \\
\hline & N10-3 & $0.92 \pm 0.03^{\mathrm{a}}$ & & $8.27 \pm 0.32^{\mathrm{a}}$ & \\
\hline & N10-4 & $0.96 \pm 0.04^{\mathrm{a}}$ & & $7.21 \pm 0.60^{\mathrm{ab}}$ & \\
\hline & $\mathrm{N} 10-5$ & $0.06 \pm 0.02^{\mathrm{c}}$ & & $0.41 \pm 0.11^{\mathrm{de}}$ & \\
\hline & N10-6 & $0.03 \pm 0.00^{\mathrm{c}}$ & & $0.31 \pm 0.06^{\mathrm{e}}$ & \\
\hline & N10-7 & $0.89 \pm 0.01^{\mathrm{a}}$ & & $1.67 \pm 1.21^{\mathrm{cd}}$ & \\
\hline & N10-8 & $0.92 \pm 0.03^{\mathrm{a}}$ & & $1.83 \pm 0.20^{\mathrm{c}}$ & \\
\hline & N10-9 & $0.20 \pm 0.21^{\mathrm{b}}$ & & $0.59 \pm 0.11^{\mathrm{de}}$ & \\
\hline & N10-10 & $0.91 \pm 0.01^{\mathrm{a}}$ & & $6.31 \pm 0.69^{b}$ & \\
\hline \multirow[t]{10}{*}{ S23 } & S23-1 & $1.93 \pm 0.20^{\mathrm{a}}$ & \multirow[t]{10}{*}{$1.63 \pm 0.60^{b}$} & $6.69 \pm 0.70^{\text {cde }}$ & \multirow[t]{10}{*}{$6.48 \pm 3.20^{\mathrm{bc}}$} \\
\hline & S23-2 & $1.79 \pm 0.05^{\mathrm{a}}$ & & $5.96 \pm 1.37^{\mathrm{de}}$ & \\
\hline & S23-3 & $1.98 \pm 0.23^{\mathrm{a}}$ & & $11.20 \pm 1.14^{\mathrm{a}}$ & \\
\hline & S23-4 & $1.84 \pm 0.14^{\mathrm{a}}$ & & $5.19 \pm 2.10^{\mathrm{e}}$ & \\
\hline & S23-5 & $0.01 \pm 0.00^{\mathrm{b}}$ & & $0.13 \pm 0.01^{\mathrm{g}}$ & \\
\hline & S23-6 & $1.79 \pm 0.05^{\mathrm{a}}$ & & $10.13 \pm 0.86^{\mathrm{ab}}$ & \\
\hline & S23-7 & $1.28 \pm 1.10^{\mathrm{a}}$ & & $7.31 \pm 0.24^{\text {cd }}$ & \\
\hline & S23-8 & $1.95 \pm 0.01^{\mathrm{a}}$ & & $3.28 \pm 0.92^{\mathrm{f}}$ & \\
\hline & S23-9 & $1.86 \pm 0.03^{\mathrm{a}}$ & & $8.34 \pm 0.22^{\mathrm{bc}}$ & \\
\hline & S23-10 & $1.88 \pm 0.01^{\mathrm{a}}$ & & $6.53 \pm 0.06^{\text {cde }}$ & \\
\hline Non-GMO & $\mathrm{CK}$ & $0.00 \pm 0.00$ & $0.00 \pm 0.00^{\mathrm{d}}$ & $0.00 \pm 0.00$ & $0.00 \pm 0.00^{\mathrm{d}}$ \\
\hline
\end{tabular}

Superscripted letters within the columns of line averages indicate significant differences $(P \leq 0.05)$ between lines for each vector; the superscripted letters within the columns of vector averages indicate significant differences among vectors $(\mathrm{P} \leq 0.05)$.

Likewise, as shown in Table 3, Cry3 A toxalbumin expression was detected in all lines and differed significantly both among the different lines and vectors $(\mathrm{P} \leq 0.05)$. The highest average toxalbumin expression level was observed in N4-transformed lines $(12.70 \mu \mathrm{g} / \mathrm{g})$,

Genetics and Molecular Research 15 (3): gmr.15038293 
whereas the lowest level was detected in N10-transformed lines $(3.46 \mu \mathrm{g} / \mathrm{g})$. The expression levels in N5- and S23-transformed lines were 8.21 and $6.48 \mu \mathrm{g} / \mathrm{g}$, respectively.

Our comprehensive analysis indicated that the Cry3A content was higher than the Cry1Ac content in lines transformed with N4, N10, and S23, whereas no difference was found in the lines transformed with N5.

\section{FQ-PCR detection}

As shown in FQ-PCR detection of CrylAc (Table 4), expression of the CrylAc fluorescence signals was detected from all lines and transcription abundance significantly differed among lines transformed with different vectors $(\mathrm{P} \leq 0.05)$. The lowest average transcription abundance was observed in S23-transformed lines $\left(3.99 \times 10^{4}\right)$, whereas the highest abundance was detected in N4-transformed lines $\left(3.17 \times 10^{5}\right)$. The transcription abundance values in N5- and N10-transformed lines were $3.15 \times 10^{5}$ and $3.12 \times 10^{5}$, respectively. In contrast, the transcription abundance of $C r y l A c$ did not differ significantly among the three representative lines transformed with different vectors $(\mathrm{P}>0.05)$.

\begin{tabular}{|c|c|c|c|c|c|c|}
\hline \multirow[t]{2}{*}{ Vectors } & \multirow[t]{2}{*}{ Line No. } & \multicolumn{2}{|c|}{ Transcript abundance of $C r y 1 A c$} & \multirow[t]{2}{*}{ Line No. } & \multicolumn{2}{|c|}{ Transcript abundance of $\mathrm{Cr} y 3 \mathrm{~A}$} \\
\hline & & Line average & Vector average & & Line average & Vector average \\
\hline \multirow[t]{3}{*}{ N4 } & N4-7 & $2.84 \times 10^{5 a}$ & \multirow[t]{3}{*}{$3.17 \times 10^{5 \mathrm{a}}$} & N4-3 & $2.83 \times 10^{7 \mathrm{a}}$ & $3.41 \times 10^{7 \mathrm{a}}$ \\
\hline & $\mathrm{N} 4-2$ & $4.39 \times 10^{5 \mathrm{a}}$ & & N4-5 & $3.04 \times 10^{7 \mathrm{a}}$ & \\
\hline & N4-6 & $2.29 \times 10^{5 \mathrm{a}}$ & & N4-7 & $4.37 \times 10^{7 \mathrm{a}}$ & \\
\hline \multirow[t]{3}{*}{ N5 } & N5-1 & $3.26 \times 10^{5 \mathrm{a}}$ & \multirow[t]{3}{*}{$3.15 \times 10^{5 \mathrm{a}}$} & N5-2 & $4.02 \times 10^{7 \mathrm{a}}$ & $3.92 \times 10^{7 \mathrm{a}}$ \\
\hline & N5-6 & $2.64 \times 10^{5 \mathrm{a}}$ & & N5-8 & $4.51 \times 10^{7 \mathrm{a}}$ & \\
\hline & N5-9 & $3.55 \times 10^{5 a}$ & & N5-1 & $3.23 \times 10^{7 \mathrm{a}}$ & \\
\hline \multirow[t]{3}{*}{ N10 } & N10-1 & $4.46 \times 10^{5 \mathrm{a}}$ & \multirow[t]{3}{*}{$3.12 \times 10^{5 \mathrm{a}}$} & N10-1 & $2.74 \times 10^{7 \mathrm{ab}}$ & $3.35 \times 10^{7 \mathrm{a}}$ \\
\hline & N10-4 & $1.96 \times 10^{5 \mathrm{a}}$ & & N10-3 & $6.57 \times 10^{7 \mathrm{a}}$ & \\
\hline & $\mathrm{N} 10-3$ & $2.93 \times 10^{5 a}$ & & N10-4 & $7.25 \times 10^{6 b}$ & \\
\hline \multirow[t]{3}{*}{ S23 } & $\mathrm{S} 23-3$ & $5.13 \times 10^{4 a}$ & \multirow[t]{3}{*}{$3.99 \times 10^{4 \mathrm{~b}}$} & S23-3 & $6.29 \times 10^{6 \mathrm{~b}}$ & $3.75 \times 10^{7 \mathrm{a}}$ \\
\hline & S23-1 & $3.77 \times 10^{4 a}$ & & S23-6 & $5.73 \times 10^{7 \mathrm{a}}$ & \\
\hline & S23-8 & $3.07 \times 10^{4 a}$ & & S23-9 & $4.89 \times 10^{7 \mathrm{a}}$ & \\
\hline
\end{tabular}

Superscripted letters within the columns of line averages indicate significant differences $(\mathrm{P} \leq 0.05)$ between lines for each vector; the superscripted letters within the columns of vector averages indicate significant differences among vectors $(\mathrm{P} \leq 0.05)$.

In contrast to CrylAc, no significant difference was found in the expression of the Cry $3 A$ fluorescence signals among the lines transformed with different vectors $(\mathrm{P}>0.05$; Table 4). The highest average transcription abundance was observed in N5-transformed lines $\left(3.92 \times 10^{7}\right)$, whereas the lowest abundance was detected in N10-transformed lines $(3.35 \mathrm{x}$ $\left.10^{7}\right)$. The transcription abundance values in the N4- and S23-transformed lines were $3.41 \mathrm{x}$ $10^{7}$ and $3.75 \times 10^{7}$, respectively. The transcription abundance of Cry $3 \mathrm{~A}$ did not significantly differ among the three lines transformed with N4 and N5 $(\mathrm{P} \leq 0.05)$, whereas differences were found among the lines transformed with N10 and S23 $(\mathrm{P} \leq 0.05)$. Our analysis indicated that the transcription abundance of $C r y 3 A$ was significantly higher than that of $C r y 1 A c$ among the lines transformed with all vectors.

\section{Insect-resistance test}

The leaves of three tobacco lines grown in the field and with the highest Cry1Ac

Genetics and Molecular Research 15 (3): gmr.15038293 
expression were fed to $H$. armigera larvae for 3 days. Mortality rate was recorded daily, and the results are shown in Table 5. The mortality rate of $H$. armigera larvae fed with transgenic leaves gradually increased with increasing days of feeding. On the third day, the mortality rate caused by vectors N5, N10, and S23 exceeded $98 \%$. We found no differences in mortality rate among the lines from these three vectors $(\mathrm{P} \leq 0.05)$. However, on the third day, the mortality rate of larvae fed with N4-transformed lines was only 40.9-45.98\%, which was higher than the non-genetically modified controls but significantly lower than that of larvae fed the other three vectors $(\mathrm{P} \leq 0.05)$. These results suggest that CrylAc gene expression plays a role when expression reaches a certain level and that a lethal effect could be obtained against the Lepidopteran pest $H$. armigera.

Table 5. Lethal effect of transgenic tobacco leaves on Helicoverpa armigera larvae (\%).

\begin{tabular}{|c|c|c|c|c|c|c|c|}
\hline \multirow[t]{2}{*}{ Vectors } & \multirow[t]{2}{*}{ Line No. } & \multicolumn{2}{|c|}{ First day } & \multicolumn{2}{|c|}{ Second day } & \multicolumn{2}{|c|}{ Third day } \\
\hline & & Line average & Vector average & Line average & Vector average & Line average & Vector average \\
\hline \multirow[t]{3}{*}{ N4 } & $\mathrm{N} 4-7$ & $13.98 \pm 5.94^{b}$ & \multirow{3}{*}{$11.18 \pm 9.21^{\mathrm{b}}$} & $34.66 \pm 5.94^{\mathrm{a}}$ & \multirow[t]{3}{*}{$33.63 \pm 3.66^{\mathrm{b}}$} & $41.34 \pm 8.36^{\mathrm{a}}$ & \multirow[t]{3}{*}{$42.74 \pm 2.81^{b}$} \\
\hline & N4-2 & $0.90 \pm 0.12^{\mathrm{c}}$ & & $29.56 \pm 4.57^{\mathrm{a}}$ & & $40.90 \pm 2.34^{\mathrm{a}}$ & \\
\hline & N4-6 & $18.66 \pm 12.16^{\mathrm{a}}$ & & $36.66 \pm 13.95^{\mathrm{a}}$ & & $45.98 \pm 8.94^{\mathrm{a}}$ & \\
\hline \multirow{3}{*}{ N5 } & N5-1 & $18.02 \pm 8.35^{\mathrm{a}}$ & \multirow{3}{*}{$15.33 \pm 4.06^{\mathrm{ab}}$} & $94.68 \pm 5.05^{\mathrm{a}}$ & \multirow[t]{3}{*}{$93.50 \pm 3.09^{\mathrm{a}}$} & $100.00 \pm 0.00^{\mathrm{a}}$ & \multirow[t]{3}{*}{$100.00 \pm 0.00^{\mathrm{a}}$} \\
\hline & N5-6 & $10.66 \pm 2.76^{\mathrm{b}}$ & & $95.83 \pm 3.21^{\mathrm{a}}$ & & $100.00 \pm 0.00^{\mathrm{a}}$ & \\
\hline & N5-9 & $17.32 \pm 5.95^{\mathrm{a}}$ & & $90.00 \pm 3.30^{\mathrm{a}}$ & & $100.00 \pm 0.00^{\mathrm{a}}$ & \\
\hline \multirow[t]{3}{*}{ N10 } & N10-1 & $18.02 \pm 8.35^{\mathrm{a}}$ & \multirow[t]{3}{*}{$16.23 \pm 8.16^{\mathrm{ab}}$} & $99.34 \pm 1.48^{\mathrm{a}}$ & \multirow[t]{3}{*}{$97.11 \pm 2.78^{\mathrm{a}}$} & $100.00 \pm 0.00^{\mathrm{a}}$ & \multirow[t]{3}{*}{$99.78 \pm 0.38^{\mathrm{a}}$} \\
\hline & \begin{tabular}{|l|} 
N10-4 \\
\end{tabular} & $23.34 \pm 5.27^{\mathrm{a}}$ & & $98.00 \pm 0.66^{\mathrm{a}}$ & & $99.34 \pm 1.48^{\mathrm{a}}$ & \\
\hline & \begin{tabular}{|l|}
$\mathrm{N} 10-3$ \\
\end{tabular} & $7.32 \pm 5.95^{\mathrm{b}}$ & & $94.00 \pm 2.81^{\mathrm{b}}$ & & $100.00 \pm 0.00^{\mathrm{a}}$ & \\
\hline \multirow[t]{3}{*}{$\bar{S} 23$} & S23-3 & $10.66 \pm 4.96^{\mathrm{c}}$ & \multirow[t]{3}{*}{$23.55 \pm 12.10^{\mathrm{a}}$} & $60.68 \pm 46.35^{\mathrm{b}}$ & \multirow[t]{3}{*}{$84.01 \pm 20.27^{\mathrm{a}}$} & $100.00 \pm 0.00^{\mathrm{a}}$ & \multirow[t]{3}{*}{$99.55 \pm 0.77^{\mathrm{a}}$} \\
\hline & S23-1 & $34.66 \pm 5.57^{\mathrm{a}}$ & & $94.00 \pm 2.81^{\mathrm{a}}$ & & $98.66 \pm 3.00^{\mathrm{a}}$ & \\
\hline & \begin{tabular}{|l|} 
S23-8 \\
\end{tabular} & $25.32 \pm 8.69^{b}$ & & $97.34 \pm 4.34^{\mathrm{a}}$ & & $100.00 \pm 0.00^{\mathrm{a}}$ & \\
\hline Non-GMO & CK & $3.33 \pm 3.35$ & $3.33 \pm 0.00^{\mathrm{c}}$ & $24.47 \pm 3.87$ & $24.47 \pm 0.00^{\mathrm{b}}$ & $24.47 \pm 3.87$ & $24.47 \pm 0.00^{\mathrm{c}}$ \\
\hline
\end{tabular}

Superscripted letters within the columns of line averages indicate significant differences $(\mathrm{P} \leq 0.05)$ between lines for each vector; the superscripted letters within the columns of vector averages indicate significant differences among vectors $(\mathrm{P} \leq 0.05)$.

For the A. germari-feeding experiment, the powdered mix of leaves from the transgenic tobacco lines and the branches of the non-transgenic $P$. tomentosa were fed to A. germari larvae for 12 days. A. germari larval weight gradually increased over time. However, the rate increase was significantly lower in larvae fed with transgenic lines, compared to larvae fed with non-transgenic lines (Figure 4). By day 12, the larval weight had increased by about $156.96 \%$ in the control non-transgenic lines, whereas it had only increased by $60.55-116.33 \%$ in the four transgenic lines. The weight of larvae fed with lines transformed with the four vectors also differed. S23-3 exhibited the maximum inhibitory effect on larval growth, whereas N5-2 presented the minimum effect. Although Cry $3 \mathrm{~A}$ toxalbumin expression differed significantly among the different lines of vectors, the four lines chosen all had a higher Cry3A toxalbumin expression level and insect resistance, it declared that when the expression reached a certain level, the growth of $A$. germari larvae, a Coleopteran pest, was obviously inhibited.

\section{DISCUSSION}

Plants transformed with $B t$ genes, which exhibit inherent insect resistance, present high ecological safety but a narrow insect-resistance spectrum (Whiteley and Schnepf, 1986). Cry $1 A c$ only provides resistance against Lepidoptera, whereas Cry $3 A$ provides resistance 


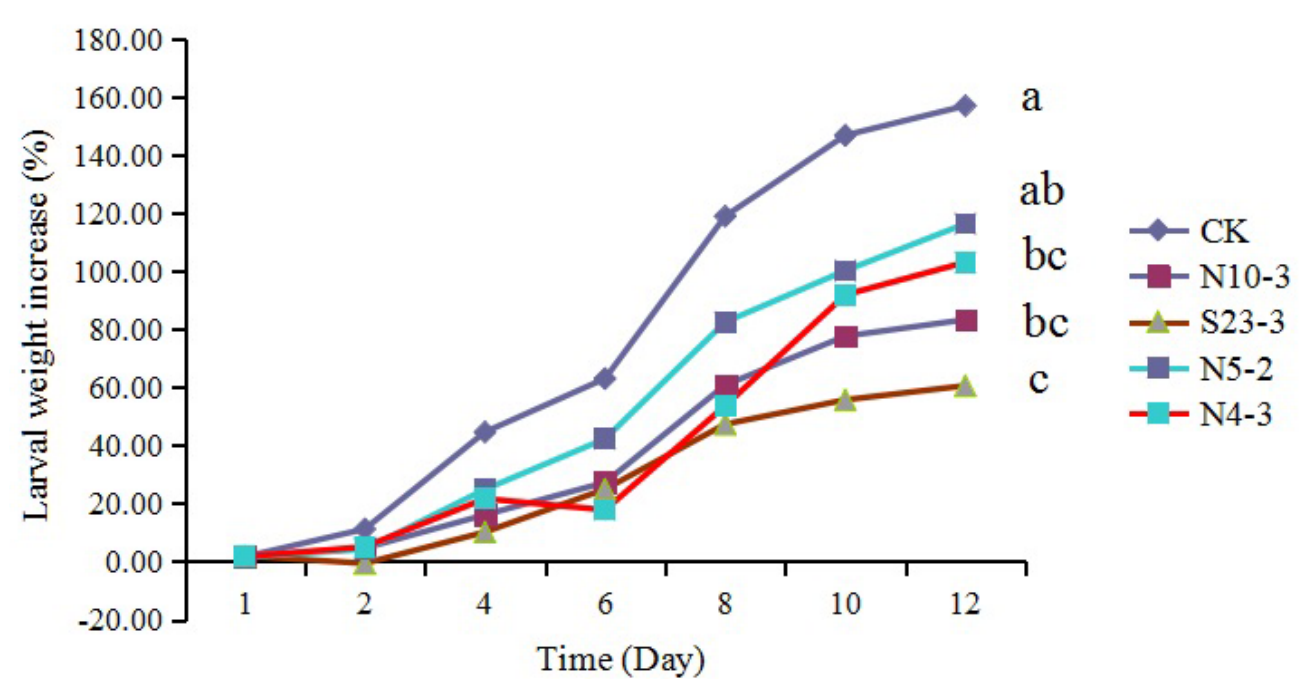

Figure 4. Influence of transgenic insect-resistant tobacco on Apriona germari larval weight. Letters to the right of the figure indicate significant differences $(\mathrm{P} \leq 0.05)$ between lines.

against Coleoptera (Zhang et al., 2006; Wang et al., 2008b). The insect-resistance spectrum and insecticidal efficacy can be improved by transforming both these genes in plants. However, interference may occur due to the high-sequence similarity or identity of these genes. In this experiment, two $B t$ genes were constructed in a vector by applying the MAR structure, applying different promoters and enhancer sequences, and changing the ORF sequence of exogenous genes. Four different types of vectors were constructed and transformed into tobacco to obtain transgenic plants. These plants were then used to investigate the influence of the vector structure on the expression of the two $B t$ genes and to screen for the optimal gene combination.

\section{Effect of $B t$ gene sequence order}

In the same transformation event, N4 and N5 differed in terms of the ORF sequence for importing the $C r y 1 A c$ and $C r y 3 A$ target genes. In N4, the ORF of CrylAc was upstream of the $C r y 3 A$ gene, near the selected marker gene $n p t I I$. In N5, the ORF of Cry $3 A$ was upstream of the CrylAc gene, near the selected marker gene nptII. Based on the toxalbumin detection results, the average expression level of Cry1 Ac toxalbumin in the transgenic lines of N5 $(8.77 \mu \mathrm{g} / \mathrm{g})$ was significantly different and 67 times higher than that in $\mathrm{N} 4$ lines $(0.13 \mu \mathrm{g} / \mathrm{g})$. Likewise, the average expression level of Cry3A toxalbumin in $\mathrm{N} 4$ lines $(12.70 \mu \mathrm{g} / \mathrm{g})$ was significantly different from, and 1.5 times higher than, that in N5 lines $(8.21 \mu \mathrm{g} / \mathrm{g})$. Thus, in these transformation vectors, the sequence of both $B t$ genes determined toxalbumin expression where the upstream $B t$ gene was inhibited, presenting lower expression levels than the downstream $B t$ genes. This effect is most evident in CrylAc gene expression. We found that the transcription levels of the two $B t$ genes did not significantly differ between the N4 and N5 lines. The transcription abundance of the $C r y 3 A$ gene was two magnitudes higher than that of the $C r y l A c$ gene in all lines. This finding is consistent with the features of the two genes that

Genetics and Molecular Research 15 (3): gmr.15038293 
had been verified in other plants (Wang et al., 2008b, 2012). Hence, the $B t$ gene sequence may affect toxalbumin translation while only having a minimal influence on gene transcription. The interaction between the two $B t$ genes may result in blocking of CrylAc protein translation, thus altering the protein structure or influencing the selected marker gene nptII. However, this finding must be further studied and validated.

\section{Enhancer effect}

An enhancer refers to a DNA sequence that increases the transcription frequency of its concatenate genes. The efficiency of target gene expression can be improved by genetically constructing vectors with certain promoters, enhancers, and other gene transcriptional regulatory elements (Mao and Guo, 1998; Jia and Zeng, 2002; Xiong and Jiang, 2011). Many studies have shown that the 5'-non-translated sequence (UTR) of eukaryotic genes is necessary for normal gene expression and that the loss of this sequence causes significant reduction in mRNA stability and translation level. For example, an omega element exists upstream of the translation initiation site of the $126-\mathrm{kDa}$ protein gene of the tobacco mosaic virus (TMV); this element consists of a 68 -bp nucleotide, which provides a new ribosome binding site, thereby improving the translation activity of the GUS gene. Currently, an omega translationenhanced sequence has been applied at the 5'-region of exogenous genes of various vectors (Gallie et al., 1987; Hou et al., 2001). The N5- and N10-enhanced sequences differed among the four vectors constructed in the present study. AtADH 5'-UTR was applied before CrylAc in N5, whereas the TMV translational enhancer omega sequence was applied before CrylAc in N10; this procedure was performed to determine the most effective enhancer in improving the expression level of $B t$ genes. In the toxalbumin detection, the average Cry1 Ac toxalbumin content was 13 times higher in the lines transformed with N5 $(8.77 \mu \mathrm{g} / \mathrm{g})$ compared to in N10 lines $(0.67 \mu \mathrm{g} / \mathrm{g})$. However, the average Cry $1 A c$ gene transcription abundance of all the lines transformed with $\mathrm{N} 5$ reached $3.15 \times 10^{5}$, which was not significantly different from that of the N10 transformed lines $\left(3.12 \times 10^{5}\right)$. Hence, AtADH 5'-UTR improved Bt toxalbumin translation for the CrylAc gene. In constructing plant transformation vectors, enhancers play an important role in increasing gene expression levels. Application of different genetic sequences before $\mathrm{Cry} / \mathrm{Ac}$ also exerted an influence on $\mathrm{Cry} 3 \mathrm{~A}$. The average Cry3A toxalbumin content was two times higher in the lines transformed with N5 $(8.21 \mu \mathrm{g} / \mathrm{g})$ than that in N10 lines $(3.46 \mu \mathrm{g} / \mathrm{g})$. Toxalbumin content did not significantly differ among N10-transformed lines, with the highest content observed in N10-3 $(8.27 \mu \mathrm{g} / \mathrm{g})$ and the lowest content in N10-6 $(0.31 \mu \mathrm{g} / \mathrm{g})$. Furthermore, $\operatorname{Cry} 3 \mathrm{~A}$ gene transcription abundance and toxalbumin expression did not significantly differ in the three lines with the highest Cry3A toxalbumin expression level in N5 and N10.

\section{MAR structure effect}

The MAR structure is a DNA sequence that combines with the nuclear matrix in chromosomes. When the MAR structure and target gene act as a single unit, plant expression vectors can be constructed without species limitation and exogenous genes can be integrated into the cellular genome. This phenomenon may improve the expression levels of exogenous genes in transgenic plants, reduce gene silencing, achieve stable expression in the current generation procedures, and reduce gene expression differences and promote stable inheritance

Genetics and Molecular Research 15 (3): gmr.15038293 
of exogenous genes in future generations (Breyne et al., 1992; Allen et al., 1993; Mlynarova et al., 1994, 1995; Zahn-Zabal et al., 2001). Li et al. (2001) constructed the pea MAR sequences on both ends of the GUS gene to form a plant transformation vector. The constructed vector and the plant transformation vector without the MAR sequence were used to transform tobacco through Agrobacterium mediation. Their results indicated that the vector containing the MAR sequences increased GUS gene expression level two- or five-fold. In the present study, both ends of the two Bt genes were inserted into the MAR sequence to construct the plant transformation vector N5. By contrast, S23 contained no MAR sequence on either side of the $B t$ genes. In toxalbumin detection, the average Cry1 Ac toxalbumin content was 5 times higher in the N5 lines transformed $(8.77 \mu \mathrm{g} / \mathrm{g})$ compared to in S23 lines $(1.63 \mu \mathrm{g} / \mathrm{g})$. Likewise, the average Cry3A toxalbumin content was 1.3 times higher in the lines transformed with $\mathrm{N} 5(8.21 \mu \mathrm{g} / \mathrm{g})$ than that in S23 lines $(6.48 \mu \mathrm{g} / \mathrm{g})$. Thus, toxalbumin expression significantly differed among the lines transformed with $\mathrm{S} 23$ vector lacking the MAR structure. In particular, the genetic difference of $C r y 3 A$ was the highest, with the coefficient of variation reaching $49.45 \%$. The toxalbumin content of S23-3 was the highest at $11.2 \mu \mathrm{g} / \mathrm{g}$, whereas that of S23-3 only reached $0.13 \mu \mathrm{g} / \mathrm{g}$. Transcription was compared among the three lines with the highest toxalbumin content in vectors N5 and S23. The transcription abundance of the CrylAc and Cry $3 A$ genes in the three lines transformed with N5 was higher than that in S23 lines. This finding indicates that the level and stability of $B t$ gene expression can be improved by applying MAR on both ends of genes.

In the same transformation event, exogenous gene expression differences existed between different transgenic lines, which has been shown in many transgenic studies. The identified reasons for expression differences between different transgenic lines vary, but the random-insert location in the host chromosome is often the main reason. When the insert location differs, the gene sequences around the integration site of the exogenous gene in the host genome could affect the exogenous expression. For example, this could lead to methylation of the exogenous gene and its promoter, transcriptional mRNA degradation resulting in no accumulation in the cytoplasm, and so on. Hence, to avoid effects of random insertion of the exogenous gene in the plant genome on gene expression in comparing the effects of different structure vectors on exogenous gene expression, multiple-transgenic lines should be obtained. Furthermore, the reliability of the obtained results should be evaluated using robust statistical analysis methods. In this experiment, 8-10 lines were transformed with each vector. We found that gene expression differed significantly both among the different vectors, as well as among the different lines within each vector, probably due to differences in the genes insert location.

\section{Insect resistance}

In the feeding experiment using lines with high Bt toxalbumin expression, all transgenic lines produced resistance against $H$. armigera and A. germari. However, the correlation between insecticidal effect and toxalbumin content was not clear. When Bt toxalbumin content reached a certain threshold, the insecticidal effect was significant in young larvae but this effect was not obviously related to toxalbumin content. As shown in the feeding test of firstinstar larvae, larval mortality rate exceeded $98 \%$ after 3 days.

Integrated analysis imply that $\mathrm{N} 5$ was the most optimal of the four tested vectors (N4, N5, N10, and S23), that CrylAc and Cry3A genes were inserted into the MAR sequence, the ORF of $C r y 3 A$ was upstream of the CrylAc gene, near the selected marker gene nptII,

Genetics and Molecular Research 15 (3): gmr.15038293 
AtADH 5'-UTR was applied before CrylAc. With the continuous development of genetic engineering technologies, research on plant transformation vectors has been optimized and plant transformation efficiency has increased. As exogenous genes are affected by various factors, such as integration location, transcription, translation and processing, and secretion in the plant genome, they could affect the accumulation of target proteins in plants. Therefore, technical strategies must be established to achieve optimal effect and meet the requirements for commercialized transgenic products in the future.

\section{Conflicts of interest}

The authors declare no conflict of interest.

\section{ACKNOWLEDGMENTS}

Research supported by the National Natural Science Foundation of China (\#31370663) and the National High-Technology Research and Development Program of China (\#863 Program; \#2013AA102703).

\section{REFERENCES}

Addison SJ and Rogers DJ (2010). Potential impact of differential production of the Cry2Ab and Cry1 Ac proteins in transgenic cotton in response to cold stress. J. Econ. Entomol. 103: 1206-1215. http://dx.doi.org/10.1603/EC09369

Allen GC, Hall Jr GE, Childs LC, Weissinger AK, et al. (1993). Scaffold attachment regions increase reporter gene expression in stably transformed plant cells. Plant Cell 5: 603-613. http://dx.doi.org/10.1105/tpc.5.6.603

Breyne P, van Montagu M, Depicker N and Gheysen G (1992). Characterization of a plant scaffold attachment region in a DNA fragment that normalizes transgene expression in tobacco. Plant Cell 4: 463-471. http://dx.doi.org/10.1105/ tpc.4.4.463

Cui XY, Chen ZY, Wu L, Liu XQ, et al. (2015). rbcS SRS4 promoter from Glycine max and its expression activity in transgenic tobacco. Genet. Mol. Res. 14: 7395-7405. http://dx.doi.org/10.4238/2015.July.3.15

Fan X, Shi X, Zhao J, Zhao R, et al. (1999). Insecticidal activity of transgenic tobacco plants expressing both Bt and CpTI genes on cotton bollworm (Helicoverpa armigera). Chin. J. Biotechnol. 15: 1-5.

Fromm ME, Morrish F, Armstrong C, Williams R, et al. (1990). Inheritance and expression of chimeric genes in the progeny of transgenic maize plants. Biotechnology 8: 833-839. http://dx.doi.org/10.1038/nbt0990-833

Gallie DR, Sleat DE, Watts JW, Turner PC, et al. (1987). The 5'-leader sequence of tobacco mosaic virus RNA enhances the expression of foreign gene transcripts in vitro and in vivo. Nucleic Acids Res. 15: 3257-3273. http://dx.doi. org $/ 10.1093 /$ nar/15.8.3257

He XJ, Zheng T, Su JQ and Chen ZD (2011). DNA extraction of 7 species plants of melastomaceae using modified CTAB method. Chin. J. Trop. Agric. 31: 73-77.

Hou BK, Xia GM and Chen ZH (2001). Strategies for optimizing expression vectors used in plant genetic engineering. Hereditas 23: 492-497.

Jia CP and Zeng YT (2002). Progress on function mechanism of enhancer. Chinese Bull. Life Sci. 14: 73-76.

Koziel MG, Beland GL, Bowman C, Carozzi NB, et al. (1993). Field performance of elite transgenic maize plants expressing an insecticidal protein derived from Bacillus thuringiensis. Biotechnology 11: 194-200. http://dx.doi. org/10.1038/nbt0293-194

Li XG, Lu ZX, Chen L, Xiao GF, et al. (2001). The influence of matrix attachment regions on transgene expression in transgenic tobaccos. Acta Bot. Sin. 43: 405-408.

Liao JY, Gao YQ, Wu QY, Zhu YC, et al. (2015). Purification of the insecticidal Cry2Ad protein from a Bt-isolated BRCHZP10 strain and toxin assay to the diamondback moth, Plutella xylostella (L.). Genet. Mol. Res. 14: 7661-7670. http://dx.doi.org/10.4238/2015.July.13.11

Mao LQ and Guo SD (1998). Relationship between $\Omega$ as well as the length of 3' poly (dA) and efficiency of gene expression. Acta Bot. Sin. 40: 1166-1168.

Genetics and Molecular Research 15 (3): gmr.15038293 
Mlynarova L, Loonen A, Heldens J, Jansen RC, et al. (1994). Reduced position effect in mature transgenic plants conferred by the chicken lysozyme matrix-associated region. Plant Cell 6: 417-426. http://dx.doi.org/10.1105/tpc.6.3.417

Mlynarova L, Jansen RC, Conner AJ, Stiekema WJ, et al. (1995). The MAR-mediated reduction in position effect can be uncoupled from copy number-dependent expression in transgenic plants. Plant Cell 7: 599-609. http://dx.doi. org/10.1105/tpc.7.5.599

Sekar V, Thompson DV, Maroney MJ, Bookland RG, et al. (1987). Molecular cloning and characterization of the insecticidal crystal protein gene of Bacillus thuringiensis var. tenebrionis. Proc. Natl. Acad. Sci. USA 84: 7036-7040. http://dx.doi.org/10.1073/pnas.84.20.7036

Stewart SD, Adamczyk Jr JJ, Knighten KS and Davis FM (2001). Impact of Bt cottons expressing one or two insecticidal proteins of Bacillus thuringiensis Berliner on growth and survival of noctuid (Lepidoptera) larvae. J. Econ. Entomol. 94: 752-760. http://dx.doi.org/10.1603/0022-0493-94.3.752

Su N, Sun M, Yang B, Meng K, et al. (2002). The insect resistance of OC and Bt transplastomic plant and the phenotype of their progenies. Yi Chuan 24: 288-292.

Tabashnik BE, Unnithan GC, Masson L, Crowder DW, et al. (2009). Asymmetrical cross-resistance between Bacillus thuringiensis toxins Cry1 Ac and Cry2Ab in pink bollworm. Proc. Natl. Acad. Sci. USA 106: 11889-11894. http:// dx.doi.org/10.1073/pnas.0901351106

Wang GY, Yang MS, Huo XM and Liu XJ (2012). Comparison of exogenous gene expression and insect-resistance ability of transgenic 741 poplars with single and double Bt genes. Acta Entomol. Sin. 55: 798-803.

Wang YB, Lang ZH, Zhang J, He KL, et al. (2008a). Ubil intron-mediated enhancement of the expression of Bt crylAh gene in transgenic maize (Zea mays L.). Chin. Sci. Bull. 53: 3185-3190.

Wang YP, Li J, Yang MS and Liang HY (2008b). Insect resistance selectivity of transgenic hybrid poplar 741. Sci. Silvae Sin. 44: 67-71.

Whiteley HR and Schnepf HE (1986). The molecular biology of parasporal crystal body formation in Bacillus thuringiensis. Annu. Rev. Microbiol. 40: 549-576. http://dx.doi.org/10.1146/annurev.mi.40.100186.003001

Xiong CJ and Jiang LM (2011). Research progress of enhancer and its bioinformatics prediction. Chem. Life 31: 446-449.

Yang MS, Liang HY, Gao BJ, Wang JM, et al. (2003). Insecticidal activity and transgene expression stability of transgenic hybrid poplar clone 741 carrying two insect-resistant genes. Silvae Genet. 52: 197-201.

Zahn-Zabal M, Kobr M, Girod PA, Imhof M, et al. (2001). Development of stable cell lines for production or regulated expression using matrix attachment regions. J. Biotechnol. 87: 29-42. http://dx.doi.org/10.1016/S0168$\underline{1656(00) 00423-5}$

Zhang BY, Su XH, Li YL, Zhang YA, et al. (2006). Production of Populus alba x P. glandulosa with a coleopterous insect resistant gene and analysis of insect resistance. J. Beijing Forest. Univ. 28: 102-105.

Zhang HY, Liu HM and Liu XZ (2015). Production of transgenic kiwifruit plants harboring the SbtCrylAc gene. Genet. Mol. Res. 14: 8483-8489. http://dx.doi.org/10.4238/2015.July.28.16

Zhang XH, Tian SR, Zhang TY, Li J, et al. (2012). Analysis of biological characteristics between the transgenic cotton harboring CrylAc+Cry2Ab double Bt genes and non-transgenic cotton. Chin. Agric. Sci. Bull. 28: 35-41.

Genetics and Molecular Research 15 (3): gmr.15038293 